\title{
輸液中における細菌の消長に関する実験的研究
}

\author{
福村ひろこ，窪田盛厚，近藤由利子, ${ }^{* 1}$ 高柳満喜子, 村田篤司*2 \\ 東邦大学医薬部附属大森病院薬剤部*1 \\ 東邦大学医学部公衆衙生教室*2
}

\section{Experimental Studies on Growth of Several Bacteria in Infusion Solutions}

\author{
HIROKO FUKUMURA, MORIATSU KUBOTA, YURIKO KONDO, *1 \\ MAKIKo TAKayanagi, TOKUSHI MURATA*2 \\ Department of Pharmacy, Toho University Omori Hospital*1 \\ Department of Public Health, School of Medicine, Toho University*z
}

(Received August 30, 1983)

\begin{abstract}
Several infusion solutions, such as $5 \%$ Dextrose injection, Hartmann's D solution ${ }^{\otimes}$, Proteamin XT® and IVH solution, were experimentally incubated with Staphylococcus aureus, Escherichia coli, Klebsiella pneumoniae, Psuedomonas aeruginosa, and Candida albicans, and were examined for bacterial growth for $24 \mathrm{hr}$. No bacterial growth was observed in these infusion solutions for $6 \mathrm{hr}$. Further, the admixtures with several vitamin intravenous solutions were also examined. Although some interbacterial variance was observed, no bacterial growth was observed in the admixtures for $24 \mathrm{hr}$. Among the bacteria examined in this study, Candida albicans was most potential for survival. These results revealed that once bacterial contamination had occurred during preparation of these infusion solutions, bacteria would survive until the completion of infusion. So we conclude that the methods and the environment involved the preparation of infusion solutions should be carefully monitored in order to minimize bacterial contamination.
\end{abstract}

Keywords_-infusion solution; $5 \%$ Dextrose injection; Hartmann's D solution; Proteamin XT; IVH solution; microbiological contamination

現在, 病院内で使用されている注射斉は厳しいGMP 規制の下で製造された極めて異物の少ないるのである.11 しかし, 点滴静注する際には輸夜に 2,3 種類の注射液 を混合する場合が多く，その段階で污染を受ける可能性 が多いとされている.11 細菌污染の要因としては調製方 法, 消毒法, 手技, 環境などが举げられ, これらに関し ては種々の検討がなされている.2,3)

当病院でも, 注射液の混合調製は使用時に病棟で医師 の指示の下に看護婦により行われているが, その際活染

*1 東京都大田区大森西 6 丁目 11-1 ; 11-1, Omori Nishi 6-chome, Ota-ku, Tokyo, 143 Japan

*2 東京都大田区大森西 5 丁目 21-16；21-16, Omori Nishi 5-chome, Ota-ku, Tokyo, 143 Japan
を受ける可能性は否定できないまた高カロリ一輸液 (以下 I V H液と略す) の組成は糖, アミノ酸, 電解 質, ビタミン類からなっているため, 特に真菌の培地に なりかねないとされている.4) 従って調製および使用時 には特に厳重な無菌操作が要求される.当院において は, 薬凧部依頼 I V H液は製剤室クリーンルーム内にお いて調製する一方, 病棟でも調製を行っているが, 近年 市販高カロリー輸液の普及に伴い病棟での調製が大部分 を占めるようになった。このような現状において微生物 污染は慎重に取り組まなくてはならない問題である．輸 液中に扩る菌の消長についての実験報告はあるが, 5,6) 短時間での消長をみたものはない，そこで今回，著者ら は注射剤混合から点滴終了までの時間を考虑して, 実際 
に翰液が污染を受けた場合の消長を実検的に検討し, 若 干の知見を得たのでここに報告する.

\section{尖方法}

\section{1. 鼓游}

当院で䇣用される輸液の中から榶質として $5 \%$ ドドウ 糖注射夜 (大赤, 以下 $5 \%$ Glucose), 電解笛としてN ルトマンD液・(ミドリ十字, 以下ハルトマンD),アミ ノ酸としてプロテァミンXT注射液・（田辺，以下プロ テアミンXT）の 3 種類を選択し，各鍮液単独および 当院において混注頪度の高い4種頼のビタミン注射液を 一定の割合で添加したもの，それに当院莯都 部調製 I V H液, 以上 7 種類を陚険液とし，各々のpHと浸适圧 比を表 1 に示した。表 1 中 Vitamin 群とはV.B とし て市販注射液メタボリンG (武田), V.B2としてフラボ ール (武田), $\mathrm{VB}_{6}$ としてピドキサール (中外) をそれ ぞれ輸液 $10 \mathrm{ml}$ 中に $0.02 \mathrm{ml}, \mathrm{V} . \mathrm{C}$ としてビタシミン （武田）を $0.04 \mathrm{ml}$ 添加したるのを表わす．また I V H 液の組成は表 2 に示した。

表 1. 使用㒛液のpH と浸还比

\begin{tabular}{l|c|c}
\hline \hline 使用 液 & $\mathrm{pH}$ & 漫透圧比 \\
\hline $5 \%$ Glucose & 4.77 & 1 \\
$5 \%$ Glucose+Vitamin群* & 5.16 & 1 \\
Hartmann & 4.52 & 2 \\
Hartmann+Vitamin群* & 4.57 & 2 \\
Proteamin XT & 6.23 & 2 \\
Proteamin XT+Vitamin群* & 6.23 & 2 \\
I V H液 & 6.27 & 4 \\
\hline
\end{tabular}

* Vitamin 群 $\left(\mathrm{V} . \mathrm{B}_{1}+\mathrm{B}_{2}+\mathrm{B}_{6}+\mathrm{C}\right): \mathrm{pH} 6.27$

実硂に使用したVitamin 紫郕

\begin{tabular}{|c|c|c|c|c|}
\hline & 商 品 名 & 会社名 & 容 & ロット番另 \\
\hline 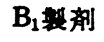 & メタボリンG & 武田 & $10 \mathrm{mg} / \mathrm{ml}$ & S01080 \\
\hline 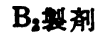 & フラボール & 武田 & $10 \mathrm{mg} / \mathrm{ml}$ & SO07 \\
\hline $\mathrm{B}_{6}$ 紫都 & ピドキサール & 中外 & $10 \mathrm{mg} / \mathrm{ml}$ & B3101 \\
\hline C 敖都 & ビタシミン & 武田 & $500 \mathrm{mg} / \mathrm{ml}$ & S561 \\
\hline
\end{tabular}

\section{2. 位用粗楼}

病院内感染菌として問題とされている菌の中からグラ 么陽性菌として Staphylococcus aureus をグラム陰性菌 として Escherichia coli, Khebsiella pneumoniae, Pseudomonas aeruginosa を, 真菌ては Candida albicans を 選択した. 使用菌株は東邦大学医学部公衆衛生学教室保 存のつぎの 5 菌株を用いた。
表 2. 当院薬荗部調製 I V H夜の組成

\begin{tabular}{|c|c|}
\hline $50 \%$ Glucose（大㴚） & $500 \mathrm{ml}$ \\
\hline Proteamin 12X (因迅) ， & $600 \mathrm{ml}$ \\
\hline Physiosol-3 (ミドリ十字) & $500 \mathrm{ml}$ \\
\hline $\mathrm{KCl}$ (丸石) & $30 \mathrm{ml}$ \\
\hline $10 \% \mathrm{NaCl}$ (大塚） & $20 \mathrm{ml}$ \\
\hline Magnesol（鳥居） & $40 \mathrm{ml}$ \\
\hline Conclyte-p ( (ドリ十字) & $40 \mathrm{ml}$ \\
\hline 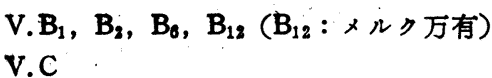 & $\begin{array}{r}\text { (各) } 30 \mathrm{ml} \\
500 \mathrm{ml}\end{array}$ \\
\hline
\end{tabular}

Total Volume $1736 \mathrm{ml}$

1) Staphylococcus aureus:209P (Staph.)

2) Escherichia coli : 患者由来株 (E. coli)

3) Klebsiella pneomoniae : 患者由来株 (Klebs.)

4) Pseudomonas aeruginosa : 患者由来株 (Ps.)

5) Candida albicans: IFO-1060 (北里研究所分与 株) Candida.

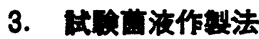

保存菌株より, 細菌は普通寒天培地 (ニッスイ) を用 いて $37^{\circ}$, 真菌はサブロー 寒天培地（栄研）を用いて $37^{\circ}$ で24時間培養した後, 隇菌生理食塩水に浮遊させ 2

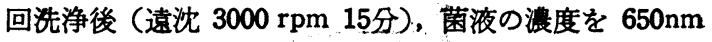
で透過率 50\% に調製し（日立-101 型 Spectrophotometer) 生菌数測定を行った。試験菌液の生菌数はおお むね $10^{7 \sim 8} / \mathrm{ml}$ であった。

\section{4. 生罡数定}

試験液 $10 \mathrm{ml}$ に試験菌液 $0.1 \mathrm{ml}$ を接種し, 室温とし

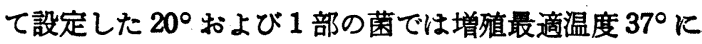

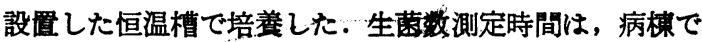
患者に点滴する際は注射液調製からら点滴終了まで約 2 〜 4 時間要することを考虑に入れ，菌接種直後，1時間， 3 時間， 6 時間，24時間後とした．各々の時間に検体を $0.1 \mathrm{ml}$ 採取して10倍段階希釈を行い，以下に示す選択培 地平板上に $0.1 \mathrm{ml}$ 取り ジンラージ棒にて広げ，細菌は $37^{\circ}, 24$ 時間, 真菌は $37^{\circ}, 48$ 時間培羪後, 生菌数の算 定を行った。平板数は 1 希釈につき 3 枚として平均集落 数を求めた。

Staph. : マンニット食塩培地（栄研）

$E$. coli : DHL 寒天培地 (栄研)

Klebs. : DHL 寒天培地 (栄研)

Ps. : NAC 寒天培地 (栄研)

Candida. : サブロ一寒天培地（栄研） 


\section{結}

\section{1. $5 \%$ Glucose における贯の消長}

$20^{\circ}$ において $5 \%$ Glucose 単独では G (十) 菌の Staph.は 6 時間後より菌数の減少がみられ，24 時間後で は菌接種時の $1 / 1000$ となった. G(一)菌の中で E.coli, Ps. はStaph. と同様 6 時間後より減少したが Klebs., Candida は 24 時間後においても接種菌数が維持された （因 1).ビタミン群を添加した場合，Staph., E. coli, Klebs., Ps. 共に 1 時間後より急激に減少し, 特に Ps. で は 1 時間後の菌数 $10 / \mathrm{ml}$ 以下と著しく低下した。しか し Candida はビタミン群添加の影響を受けず接種時の 菌数が維持された。

$37^{\circ}$ において $5 \%$ Glucose 単独ではStaph.は1時間 後より急激汇菌数が減少し，E. coli，Ps．も6時間後よ り減少がみられ，20よりる菌の発育が抑制される傾向 が示された. ビタミン群添加時はStaph., E. coli, Ps. 共に $20^{\circ}$ と同程度の減少がみられた。
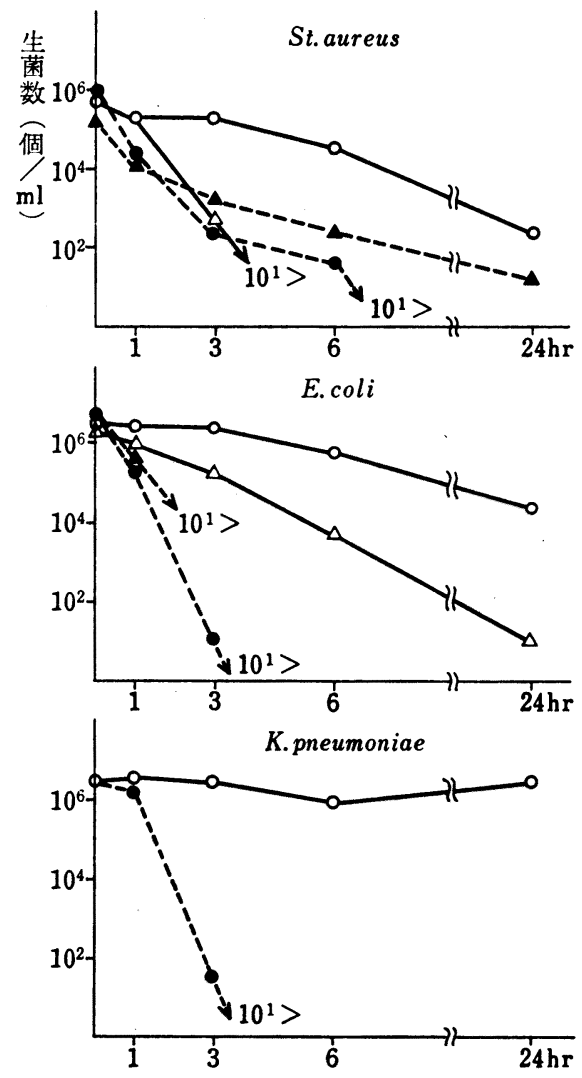

ビタミン群添加により Candida 以外の細菌ではすべ ての菌数が减少した.この原因の詳紐は不明であるが， アスコルビン酸による細菌発育抑制の報告すある. ${ }^{7 \sim 9)}$ 村田ら9は济 はアスコルビン酸はある種の細菌に対し殺菌作 用を有するが，酵母に注影䇾を及ぱさないとし，さらに 微生物の增殖にはある種のビタミンは効果はあるが，そ の量は微量であり，適量以上では微生物の增殖は抑えら れ，さらに大量ではコロニー形成能が減少することがあ ると報告している。

著者らの方法とは接種菌数に違いがあり, 温度条件の

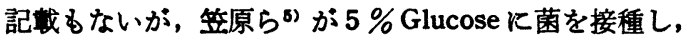
7 日間観察した報告によれば，接種 7 日後において Klebs. と Candida は增殖傾向を示している. 今回著者 らの実験では，輸液と他の注射液を混合調製後 1 日以上 保管することは当病院の現状ではみられないため，24时 間の観察にとどめた。

\section{Hartmann D における苗の消畏}

$20^{\circ}$ において Hartmann D 単独では $G(+)$ 菌の

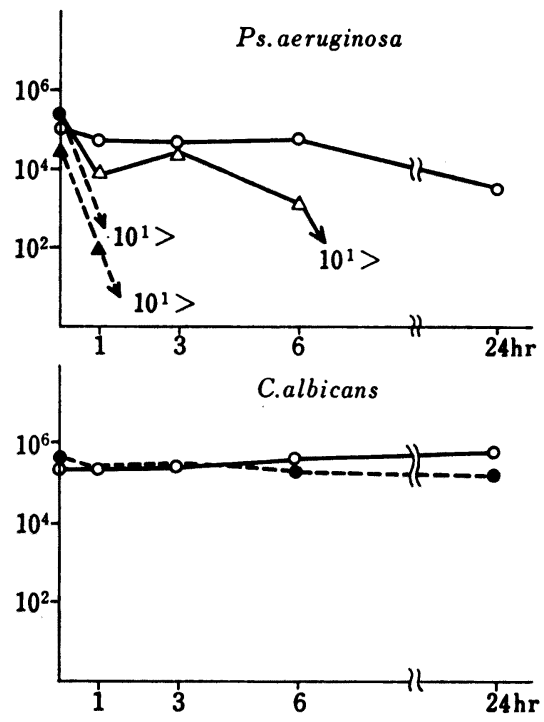

$5 \%$ Glucose

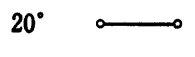

$37^{\circ}$

$5 \%$ Glucose + Vitamin群

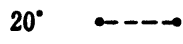

$37^{\circ}$

因 1. $5 \%$ Glucose および $5 \%$ Glucose+Vitamin 群における菌の消長 
Staph. と G(一) 腸内細菌の E. coli とKlebs. および Candida は24 時間後においても接種菌数が維持された が，Ps.は1時間後より減少傾向を示した（図 2).ビタ ミン群添加時は E. coli と Klebs. は24時間後において す単独時と同様に接種菌数が維持されたが，Staph.は 1 時間以後減少傾向を示し，Ps. はさらに急激な減少が みられた. 以上の結果より Hartmann D においてはビ タミン群添加の有無にかかわらず $\mathrm{G}(-)$ 菌の らち, $E$. coli, Klebs. は接種菌数が維持され，Ps. は発育が抑制 された。

$37^{\circ}$ において Hartmann D 単独では Staph., E. coli は 6 時間後より減少し始め, $20^{\circ}$ と異なる傾向を示した. Ps. は $20^{\circ}$ とほぼ同程度の減少傾向を示した. ビタミン 群添加時はStaph. とPs.は20\%の場合と同様 1 時間よ り減少したが，E. coli は $20^{\circ}$ の場合と異なり 6 時間以 後減少した.

\section{3. プロテアミンX Tにおける菌の消長}

$20^{\circ}$ においてビタミン群添加の有無にかかわらず,
Staph., E. coli, Klebs., Ps., Candida 共に 24 時間後 に拈いても接種菌数が維持された（図 3 ). 37\%において す同傾向を示した. プロテアミンXTにおいてこのよう に接種菌数が維持された理由の 1 つとして,アミノ酸自 体が菌の增殖に必要な栄養源として十分でなくとも，菌 生存のための緩衝液としての役割をはたしているという ことも考えられる.

\section{4.ＩVH洨における苜の消畏}

$20^{\circ}$ において Staph., E. coli, Klebs., Ps., Candida 共に24時間後においても接種時の菌数が維持された（図 4 ). 370においても同傾向を示した. I V H液組成中に は高濃度の糖質が含まれるため, 糖アルコール発酵をす る Candida の発育に適しているといら報告 ${ }^{10,11)}$ は以前 よりあるが，著者らの実験では24時間後は明らかな増殖 傾向までは示さず接種菌数が維持された．24時間以降の 傾向については，著者らの I V H液と組成および接種菌 数は異なるが, 笠原, ${ }^{5)}$ 真島 ${ }^{6)}$ らの報告があり, 真島ら は 37，3日後に おいて Staph., E. coli, Klebs., Ps.
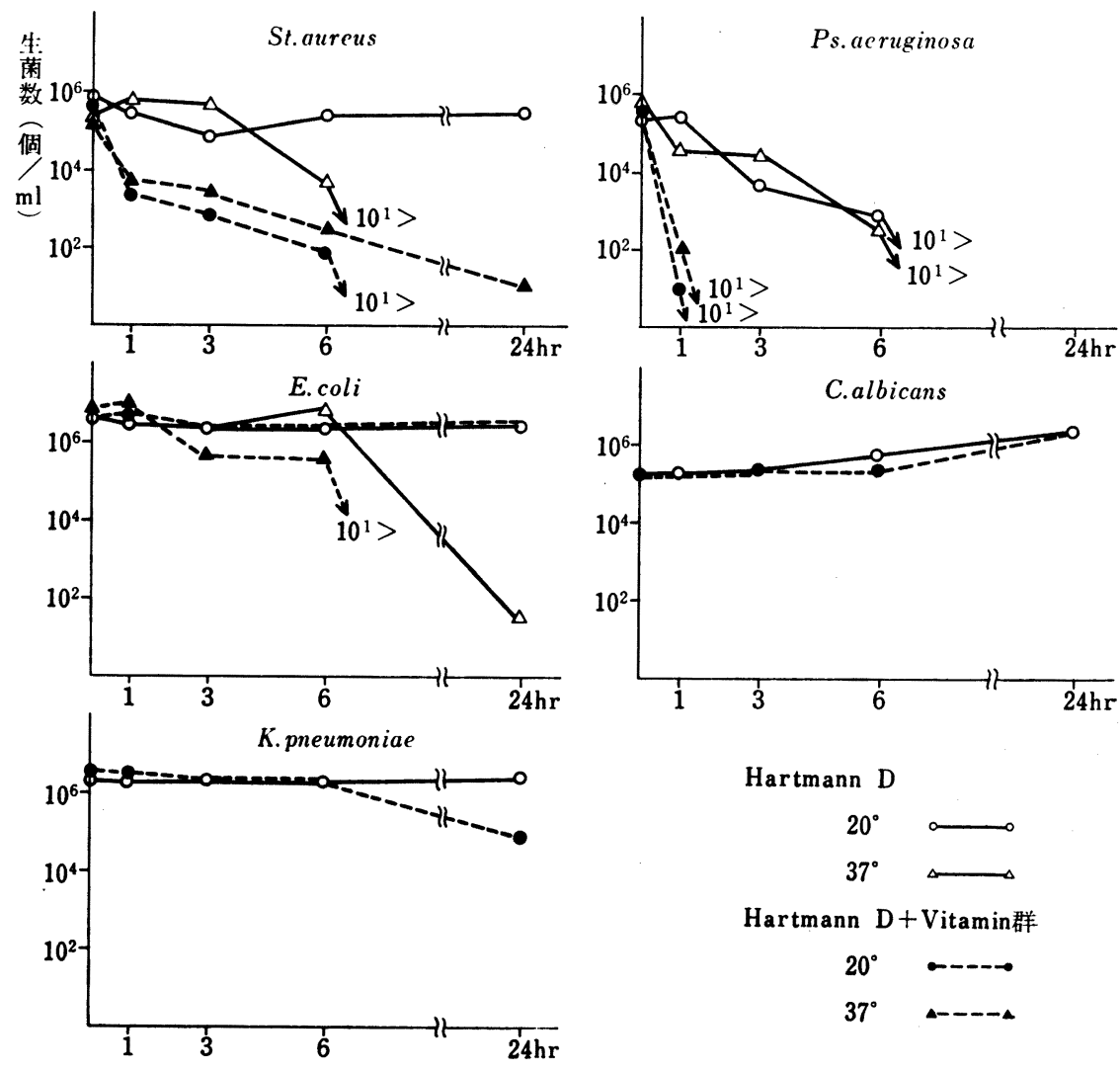

困 2. Hartmann D および Hartmann D+Vitamin 群における菌の消長 

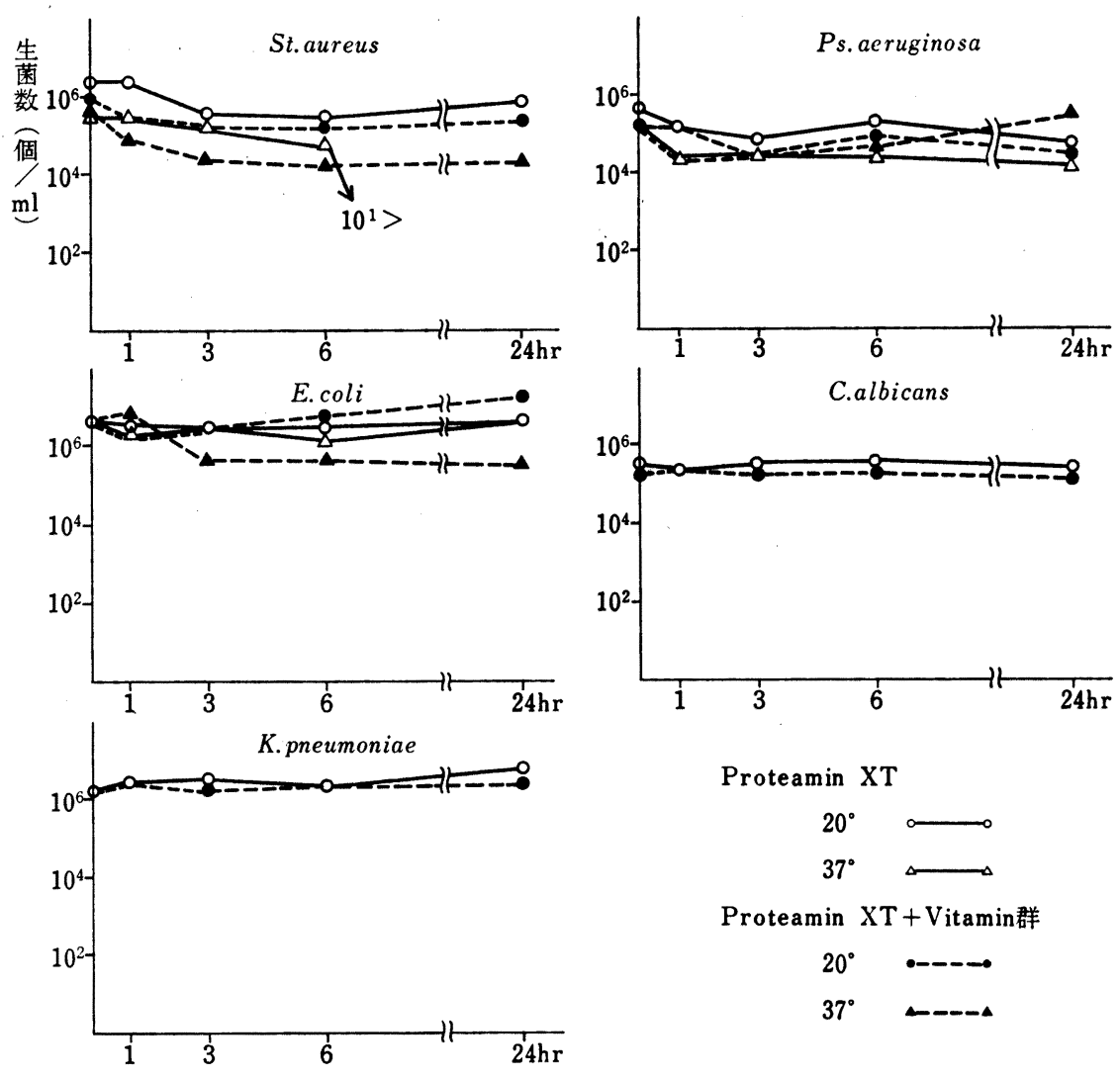

Proteamin XT

37

Proteamin XT + Vitamin群

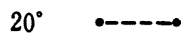

$37^{\circ}$

図 3. Proteamin XT および Proteamin XT+Vitamin 群における菌の消長

減少傾向を示し, Candidaは増殖傾向を示したとして いる. 一方, 笠原 ${ }^{5}$ らの報告では温度条件の記載はない が，7 日後に拈いて, Staph, E. coli, Ps. は減少傾向を 示し Klebs., Candida は増殖傾向を示したとしている. 両者ともに Candida は I V H 液中で増殖傾向を示すと して扣り，前述のように I V H 液は Candida の発育に 適していると推測される。

\section{考荠}

点滴静注の際の注射液の混合は, 使用時病棟で行わ れ, 配合薬品数は $3 \sim 5$ 種類が多いとされている.1 院でも病棟では患者数が多いため, 混合調製終了から患 者に注入するまでに 1 時間余り要する.さらに注入開始 から終了までは容量により異なるが 1 ～時間を要する 場合が多く，これらを合わせると調製から点滴終了まで 約 4 時間要すると考えられる.このような状態で実際に 輸液が調製時に污染された場合の輸液中に拈ける菌の消 長については，1〜 7 日といった長時間観察の報告はあ
るが，5,6) 実際に即した短時間の報告はみられなかった。 そこで著者らは24時間以内の観察を行った。

本実験では，実験的に接種した菌はビタミン無添加の $5 \%$ Glucose, Hartmann D, Proteamin TX および I VH液のいずれにおいても調製後 6 時間程度までは接 種菌数が維持され，それ以降減少するものと増殖傾向を 示するのとに分かれた．実際には調製時に今回接種した ほどの多量の污染を受けることはないと思われるが，污 染の多少にかかわらず，調製時の污染は点滴終了時まで 持続していると考えるべきであることが示唆された。ま た，6時間以後增殖傾向を示するのるあることから，污 染の可能性を考えた場合調製後のすみやかな使用が望ま れる。

ビタミン群を添加した場合は Proteamin XT, I V H 液では輸液単独の場合と同様に菌数は維持されたが, $5 \%$ Glucose, Hartmann D では菌種により $1 〜 3$ 時 間で減少するものもあった。 また, Candida は $5 \%$ Glucose, Hartmann D, Proteamin XT 中ではビタミ 

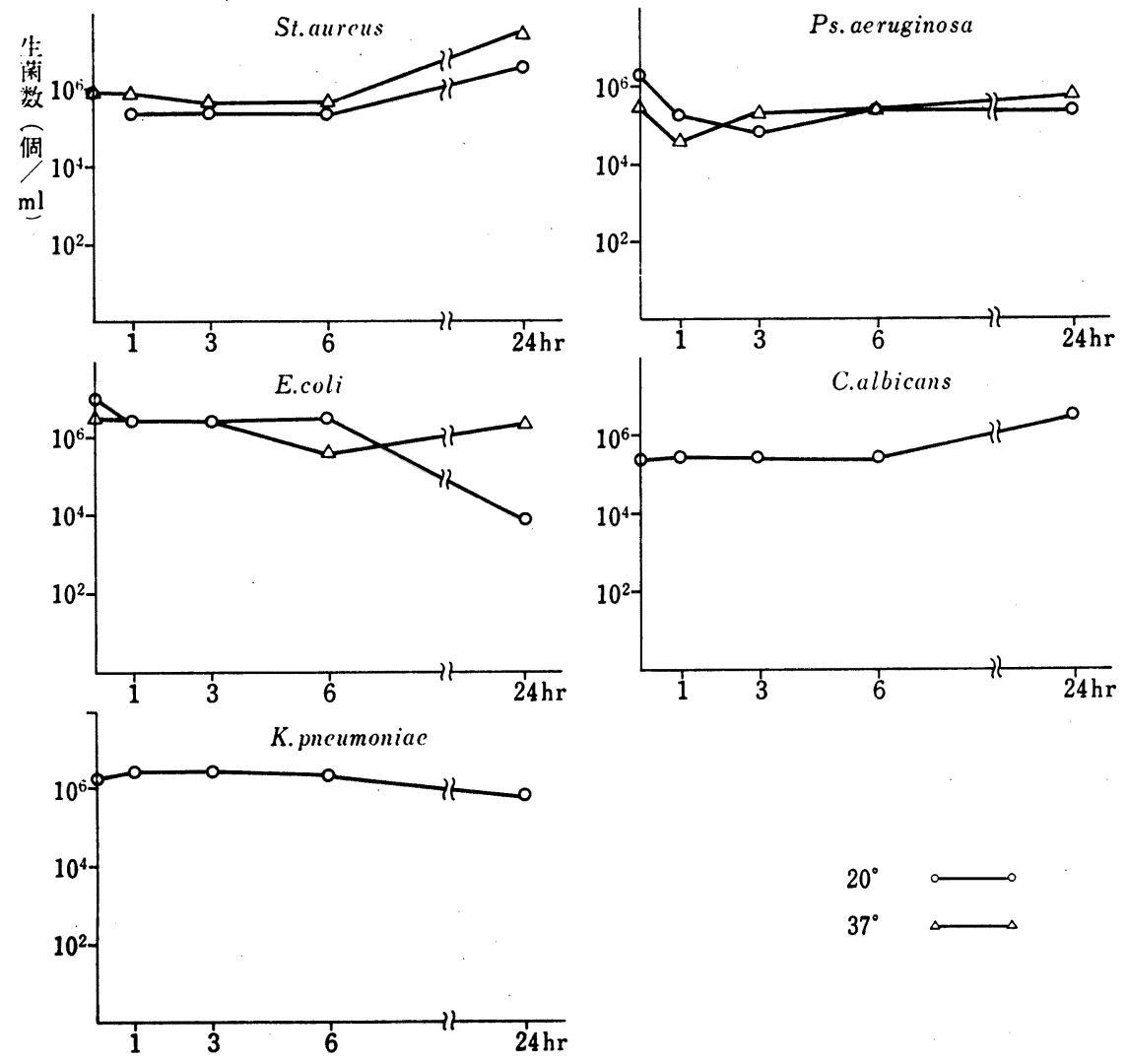

因 4. I V H液におけろ菌の消長

ン群添加の有無に関係なく、また I V H液中です24時間 後まで接種菌数が維持された.この結果よりCandidaは 他の菌と比較して輸夜中に拈ける生存力が強いと思わ れる. I V H液使用に際してカテーテル污染の原因菌と して Candida, Klebsiella, Staphylococcus 等が検出さ れ，特飞 Candida による污染率が高いことは多く報告 されている10,11)が，本実験結果からもこれらの菌種では 接種菌数が I V H液中で維持されることが確認された。

当院では昭和53年に乗郕部クリーンルーム調製 I V H 液の残液と病棟調製，I V H液の残液について細菌試験 を行った。 ${ }^{12)}$ その結果, 莱㨈部クリーンルーム調製 I V H液の使用残液では41検体中11例 $(26.8 \%)$ の菌陽性率 であったのに対し，病棵調製 I V H液残液では10検体中 7 例 (70\%) と高い陽性率を示した。 また他施設におけ る報告14でる病楝調製 I V H液の污染率の高いことが示 されている. 以上の結果より,クリーンルームのない病 槙での調製には十分な注意が望まれる。

また，実験的に菌を接種した場合の菌の消長は，輸
液, 菌種により差が現れることが示された。実際には輸 液調製段階で本実験のように多量の菌による污染を受け ることはないと思われるが，免疫能を含めた一般抵抗力 の低下した宿主では少量の菌でも感染を起こす可能性も 否定できない，ゆえに今後，輸液調製時における混合方 法、環境改善などを検討し，污染を最小限にとどめる努 カが必要であろうと考える.

\section{文塥}

1）青山敏信: 月刊薬事, 16 (10), 87 (1974).

2) B. Gunnarsson, et al.: Acta Pharm. Suec., 15, 169 (1978).

3) E. Morgan, et al.: Am. J. Hosp. Pharm., 29, 1020 (1972).

4) 鳥畑一：東北医誌, 22 (83), 364 (1938).

5) 佐々木利高 : 北海道医誌, 16, 319 (1941).

6）村田晃, 矢野信子：ビタミン, 51 (7), 312 (1977).

7）笠原伸元, 藤井康子, 佐藤健太郎, 土師久幸, 小 野晴久, 平岡栄一, 岡田正: 外科治療, 34 (6), 
655 (1976).

8) 小越章平: 月刊薬事, 21 (1), 87 (1979).

9) 藤田秀春：月刊薬事, 24 (9), 53 (1982).

10）真島吉也, 樋口道雄, 宮司勝, 永野耕士, 伊藤健 次郎, 小越章平: 臨床外科, 32 (3), 393 (1977).

11）幸保交治：“注射薬便覧,”南山堂，1976.
12）窪田盛厚, 上島待子, 福村ひろこ, 近藤芳子, 石 坂哲夫, 村田篤司, 高柳満喜子：日本薬学会98年 会講演要旨集, $136,1978$.

13）藤戸博, 中野上り子, 奥平徹, 徳永光平, 於保 誠：医薬シャーナル，16(9), 33 (1980).

\section{劇 胆汁分泌促進剤}

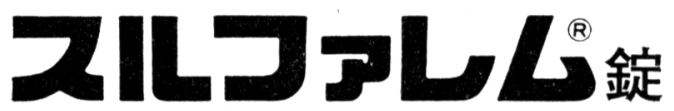

アネトールトリチオン $12.5 \mathrm{mg} /$ 錠 含有

〔適 充 症〕下記疾患に打ける利胆

胆道 (胆管・胆のう) 系疾患及び胆 汁うっ㴖支伴う肝疾患

〔用法用量〕アネトールトリチオンとして通常成 人 1 回 $25 \mathrm{mg}$ を 1 日 3 回経口投与 年令・症状により適宜増減

〔薬理作用〕 (1) 催胆作用

(2) 肝機能賦活作用 (血中 G S H 值上 昇/色素排泄能促進/尿素合成能 促進 / 肺コレステロール量調整)

薬理作用の詳細及び使用上の注意については製品 添付文書をご参照下さい。

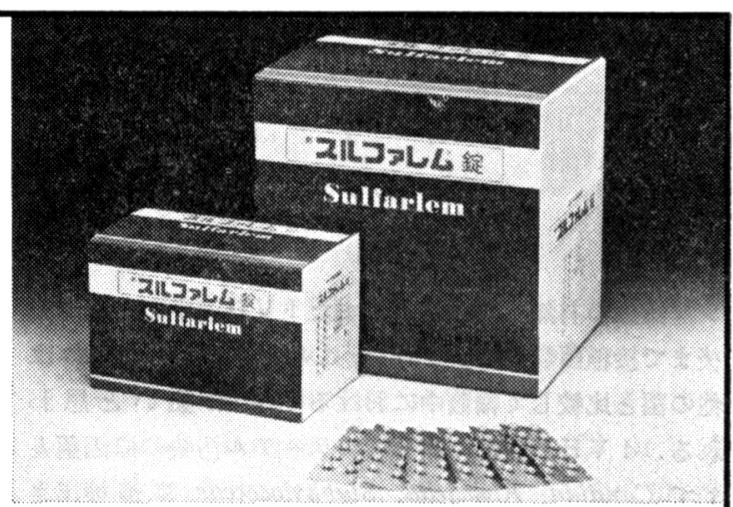

〔包装

1,200 錠 6,000 錠

(P'TP) 10錠 $\times 12010$ 錠 $\times 600$

○同一成分製剂にスルファレム丸 $(12.5 \mathrm{mg} /$ 丸)があります。 規制区分：劇 薬

薬価基準収載品

製造東菱薬品工業株式会社 東京都千代田区有楽町1-10-1

提携 ラ テ マ 社 (フランス) 販 売 元

扶桑薬品工業株式会社 